\title{
Radiocarbon
}

1988

\section{RADIOCARBON DATING OF HOLOCENE CALCAREOUS TUFA IN SOUTHERN POLAND}

\author{
ANNA PAZDUR, MIECZYSKAW F PAZDUR \\ Radiocarbon Laboratory, Institute of Physics, Silesian Technical \\ University, Krzywoustego 2, PL-44-100 Gliwice, Poland
}

and

JOACHIM SZULC

Institute of Geological Sciences, Jagellonian University, Oleandry 2a PL-30-056 Cracow, Poland

\begin{abstract}
Calcareous tufa from five sites in southern Poland, representing several most typical conditions of tufa sedimentation, were chosen for ${ }^{14} \mathrm{C},{ }^{13} \mathrm{C}$, and ${ }^{18} \mathrm{O}$ measurements. These tufas were deposited in a high-energy turbulent stream (the Racławka site), in streams with moderate but variable flow (Rzerzuśnia and Trzebienice), and in semilimnic conditions (Sieradowice site). Sediments of the Gliczarów site represent spring travertines. In all but the latter site, direct comparison of ${ }^{14} \mathrm{C}$ dates of carbonate and organic fractions was possible, leading to an estimate of initial apparent age of carbonate sediments. Clear correlation was found between the value of initial apparent age of tufas and the hydrodynamic conditions of sedimentation. Corresponding values range from ca $3900 \mathrm{yr}$ (Racławka) to $910 \mathrm{yr}$ for semilimnic sediments (Sieradowice). Intermediate, almost identical values, equal to $2460 \pm 200 \mathrm{yr}$ and $2100 \pm 160 \mathrm{yr}$, were obtained for tufas from Rzerzuśnia and Trzebienice, respectively. Detailed sedimentologic classification of tufaceous deposits is presented and some primary and secondary factors affecting the accuracy of radiocarbon dates of various types of tufas are also discussed.
\end{abstract}

\section{INTRODUCTION}

Authigenic calcareous sediments precipitated most frequently from emergent spring water, and also from stream water, are usually called travertines or calcareous tufas. $\mathrm{CaCO}_{3}$ precipitation occurs from bicarbonates dissolved in water as an effect of decrease of $\mathrm{CO}_{2}$ partial pressure, which, in turn, may be caused either by physical mechanisms such as a rise in water temperature and increase of turbulence, or by consumption of carbon dioxide in photosynthesis. Some types of calcareous tufa can also result from microbial processes. Speleothems, pedogenic carbonates (caliche, concretions, etc), eolianites, and lacustrine chalk are not classified as tufas (Szulc, 1984), though some types of tufas are deposted in semilimnic environments typified by shallow, stagnant water. Calcareous tufa and travertine are rarely used for radiocarbon dating. The only systematic studies on ${ }^{14} \mathrm{C}$ dating of tufa are those undertaken by Srdoc et al $(1980,1982,1983)$ in the Croatian Karst in Y'ugoslavia and by Thorpe, Otlet, and Sweeting (1980) and Thorpe et al (1981) on a few sites in the United Kingdom.

Much more attention has been paid to studies of geochemical processes connected with sedimentation of tufas and travertines (Gonfiantini, 
Panichi \& Tongiorgi, 1968; Friedman, 1970; Usdowski, Hoefs \& Menschel, 1979; Demovic, Hoefs \& Wedepohl, 1972; Manfra, Masi \& Turi, 1976; Buccino et al, 1978; D'Argenio et al, 1983). Calcareous tufas and travertines connected with Devonian, Lower Carboniferous, Jurassic or Cretaceous limestones and marls occur at many sites in southern Poland, especially in the Cracow-Wielun Upland. Recent studies have also revealed many sites with tufaceous sediments in northern Poland, where they are associated with Pleistocene sediments of glacial origin. Several outstanding profiles of tufaceous sediments have led to detailed reconstructions of paleoclimate and environment, based on sedimentologic features (Szulc, 1983) and malacologic studies (Alexandrowicz, 1983). Application of $\delta^{18} \mathrm{O}$ measurements provide a sensitive, independent tool for monitoring paleotemperatures. Such potential applications of tufaceous sediments call for reliable dating methods.

Research at the Radiocarbon Laboratory in Gliwice aims at determining suitability and reliability of different methods of absolute dating which could, in theory, be used for dating calcareous tufas. Such methods include thermoluminescence (TL), Electron Spin Resonance (ESR), and ${ }^{14} \mathrm{C}$. Preliminary ${ }^{14} \mathrm{C}$ results have been published (Pazdur \& Pazdur, 1986). We present here the complete results obtained for the reliability of ${ }^{14} \mathrm{C}$ dating of various types of tufas. Geologic and sedimentologic studies indicate that tufaceous sediments include highly diversified sub-types depending on chemical, biochemical, and hydrodynamic conditions of sedimentation (Szulc, 1984). A series of sites were chosen (Fig 1) as representative of different sedimentation regimes, from tufas typical of high-energy fluvial conditions at the Racławka site to semilimnic calcareous sediments at the Sieradowice site. Detailed discussion of the results of $\delta^{13} \mathrm{C}$ and $\delta^{18} \mathrm{O}$ measurements and their paleoclimatic interpretation will be presented in a forthcoming paper (Pazdur et al, $\mathrm{ms}$ in preparation).

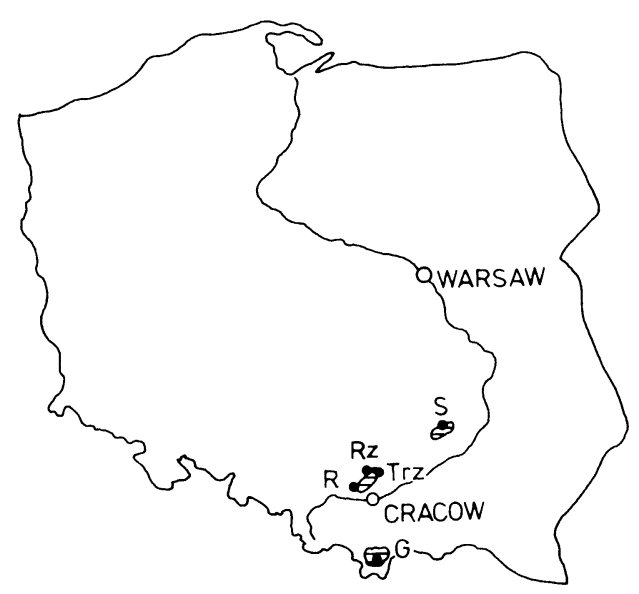

Fig 1. Location of sites. Dashed areas-regions of frequent occurrence of tufa deposits. Sites: G-Gliczarów, R-Racławka, Rz-Rzerzuśnia, S-Sieradowice, Trz-Trzebienice. 



Fig 2. Internal structure of various types of biogenic tufas: 2A. Moss travertine. Note the primary sediment (more porous irregular fabrics) and several generations of cements filling the voids. Negative print of thin section. Scale bar $=3 \mathrm{~mm}$. 2B. Cladophora tufa. Three types of sediment are visible: the primary thin encrustation of the filaments, the "dog-tooth" cements around them, and loose calcite detritus in voids. Thin section, crossed nicols. Scale bar = $300 \mu \mathrm{m}$. 2C. Stromatolite fabric, consisting of the Phormidium layer (middle, more porous part of the sediment) enclosed by dense Schizothrix laminae. Sample is $\mathrm{ca} 2000$ yr old. Note lack of any diagenetic changes. Negative print of thin section. Scale bar $=2 \mathrm{~mm}$. 2D.E. Oncoids. Note very distinct bipartition. The cortex of the upper one (2D) was developed on the older oncoid (light part). In the lower sample (2E) thin cortex is coating the large fragment of older moss travertine with snails $(\mathrm{g})$. Negative prints of thin sections. Scale bars $=2 \mathrm{~mm}$ in upper part (2D) and $5 \mathrm{~mm}$ in lower part (2E). 2F. Peloidal mud, partly aggregated. Negative print of thin section. Scale bar $=1 \mathrm{~mm}$. 


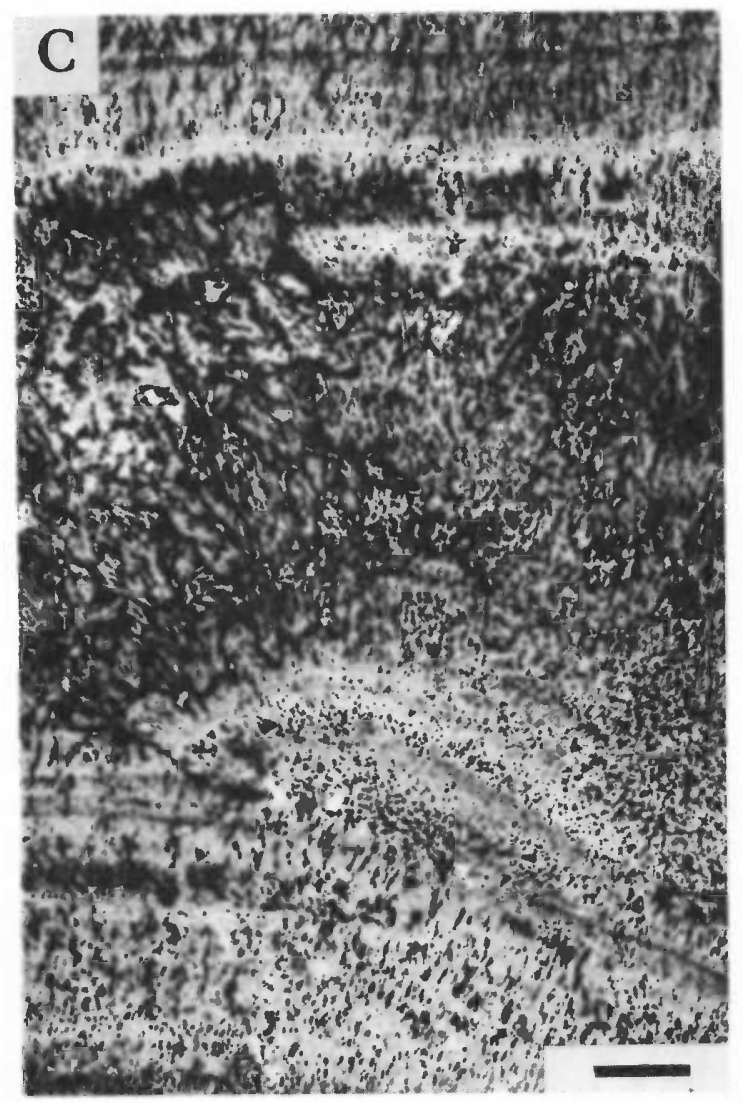

Fig 2. (continued)

\section{CLASSIFICATION OF TUFACEOUS SEDIMENTS}

In general, two groups of tufaceous sediments can be distinguished, namely abiogenic and biogenic tufas. Abiogenic tufa, called calcareous sinter, is deposited as laminated, nonporous, and firm crusts, similar to cave dripstones. It commonly occurs close to the point of emergence of spring waters with high $\mathrm{CO}_{2}$ partial pressure, where fast degassing leads to chemical precipitation of $\mathrm{CaCO}_{3}$.

Biogenic tufas, genetically and texturally connected with the presence of hygrophytes, are much more diverse. The following subgroups are distinguished here:

- massive, very porous but firm moss travertines (Fig 2A),

- nonlaminated, porous, and fragile tufas developed on higher algae threads (eg, Cladophora, Vaucheria, Fig 2B),

- laminated, porous, but very dense blue-green algal fabrics: sheetyshaped stromatolites (Fig 2C) and spheroidal oncoids (Fig 2D, E).

- calcareous muds, composed of fine-grained (peloidal) carbonate agglomerates (Fig 2F).

In general, moss travertines and most algal fabrics are deposited in 

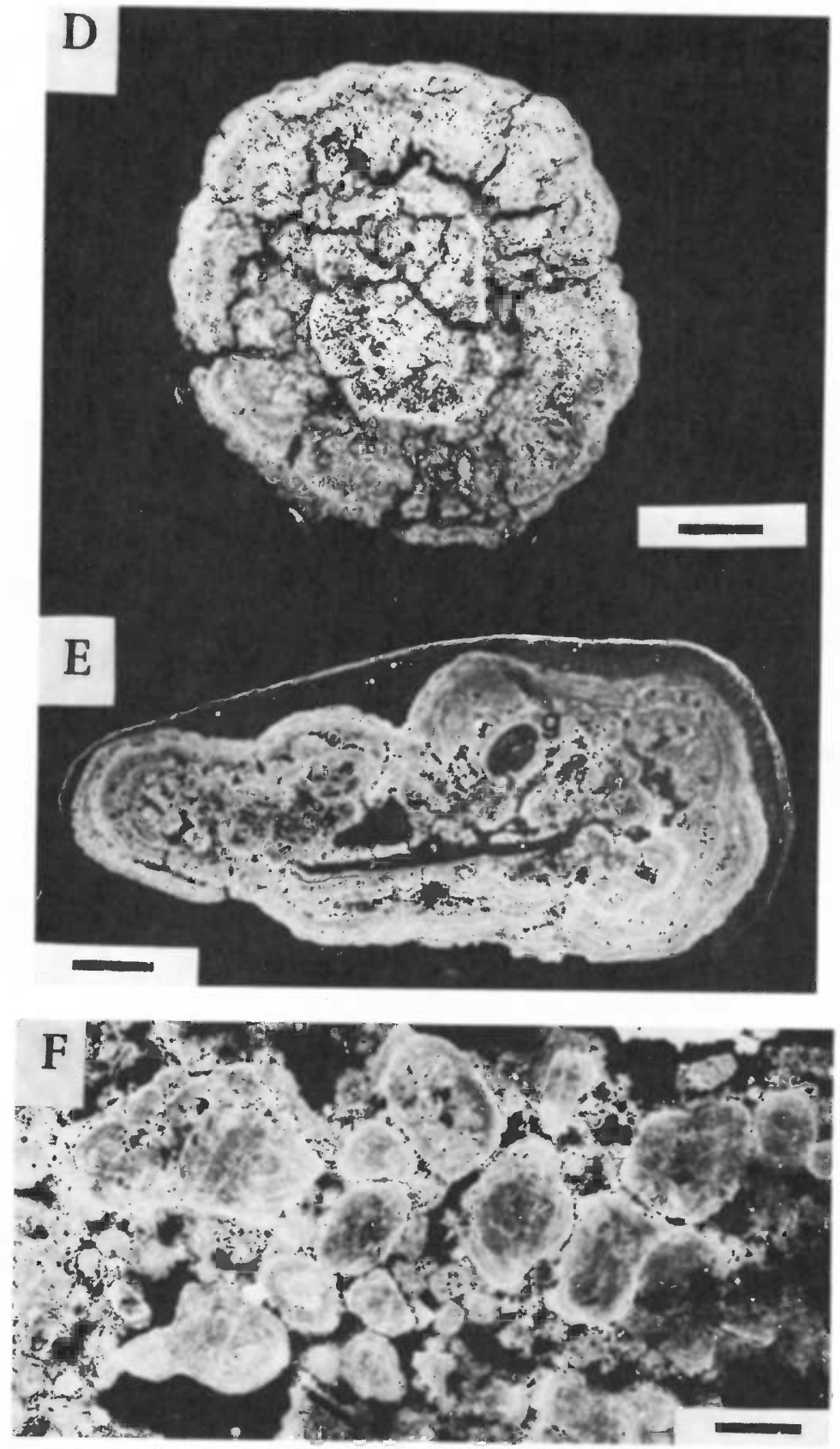

Fig 2. (continued) 


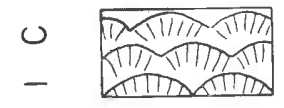

oncoids

w

0

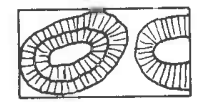

$\bigcirc$

$$
-
$$

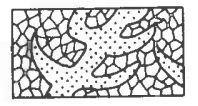

moss

$\infty$

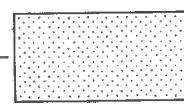

calcareous mud

\section{ABIOGENIC}

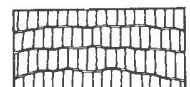

sinter

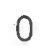

0

0

$+++$

0

Fig 3. Characterization of errors in ${ }^{14} \mathrm{C}$ dating of tufa deposits caused by postdepositional changes. Qualitative scale of susceptibility to redeposition and diagenesis: $\mathrm{O}=$ null, $+=$ weak, $++=$ moderate, $+++=$ high .

highly energetic water (eg, at waterfalls or rapids); oncoids are formed in both turbulent environments and low-energy water, and peloidal muds in stagnant water basins.

\section{SELECTION OF TUFA SAMPLES FOR ${ }^{14} \mathrm{C}$ DATING}

Authigenicity of tufaceous deposits should be regarded as the conditio sine qua non for reliable ${ }^{14} \mathrm{C}$ dating. Detailed sedimentologic examination of samples is, therefore, required before dating. Because postdepositional carbonate dissolution and reprecipitation is a possibility, careful microscopic examination of samples is necessary to select those samples with the least evidence of secondary changes. Diagenesis of tufaceous deposits is rel-

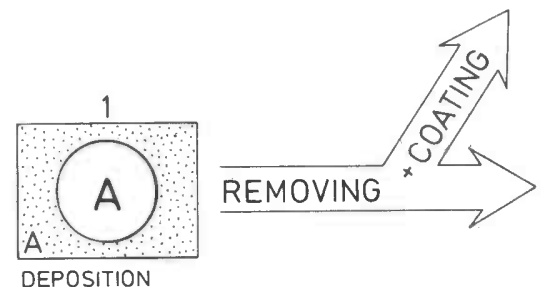

Fig 4. Difficulties of interpretation of ${ }^{14} \mathrm{C}$ dates obtained on oncoids. 1. Initial stage, age of a bed is equal to the age of oncoid. 2a. Process of simple redeposition. Oncoids are older than the secondary bed. $2 \mathrm{~b}$. Process of redeposition with simultaneous coating. 3. Subsequent redeposition without coating. 
atively fast in the geologic time scale (Szulc, 1984) and must, therefore, be considered within the range of the ${ }^{14} \mathrm{C}$ method.

The reliability of ${ }^{14} \mathrm{C}$ dates on different tufa types can be estimated from individual susceptibility to redeposition and diagenesis, as shown in Figure 3. Sinter and Cyanophyta stromatolites can be regarded as the most reliable material for ${ }^{14} \mathrm{C}$ dating, as their authigenic position in the profile is unquestionable and diagenetic changes are negligible. Oncoids are usually very weakly changed by diagenesis but their redeposition may be difficult to recognize at times. Moreover, the innermost part of the oncoid (core) is commonly older than the outer layer (cortex). Difficulties that may arise in interpreting ${ }^{14} \mathrm{C}$ dates obtained on oncoids are illustrated in Figure 4. Nonlaminated, porous algal fabrics are less favorable for ${ }^{14} \mathrm{C}$ dating because of the possibility of contamination of original carbonate with incidental impurities that may fill the voids. Moss travertines are believed to present the least reliable material for ${ }^{14} \mathrm{C}$ dating because their massive and porous texture promotes long and relatively free water circulation, leading to dissolution and reprecipitation of carbonate. As a result of these processes in old tufas, we may often observe several generations of cements of different age. It is difficult to recognize the authigenic position of peloidal calcareous muds, but their diagenetic changes are usually rather small.

\section{ORGANIC COMPONENTS OF TUFACEOUS DEPOSITS}

The results of ${ }^{14} \mathrm{C}$ dating of calcareous tufas are usually checked by comparing them with the corresponding ${ }^{14} \mathrm{C}$ dates obtained on samples of organic matter either incorporated in or adjacent to the sediment. The organic fraction may be dispersed in the calcareous matrix or embedded in the form of separate laminae or lenticles. Wood fragments can also occur in the carbonate matrix.

Organics are common in fine-grained sediments deposited in lowenergy environment, and are often intercalated in the form of peaty horizons. In tufas deposited in turbulent water, organics are scarce and occur mainly as randomly anchored branches. Calcareous gyttja seems to be the most favorable for reliable comparison of ${ }^{14} \mathrm{C}$ dates of $\mathrm{CaCO}_{3}$ and organic matter because of contemporaneous precipitation of carbonate and accumulation of organic matter.

\section{LABORATORY METHODS}

All ${ }^{14} \mathrm{C}$ measurements were made in the Radiocarbon Laboratory in Gliwice using $\mathrm{CO}_{2}$ proportional counters. For measurements of ${ }^{14} \mathrm{C}$ concentration in tufa carbonate, the $\mathrm{CO}_{2}$ was directly evolved from ca $50 \mathrm{~g}$ samples of $\mathrm{CaCO}_{3}$ by treatment with $8 \% \mathrm{HCl}$. Standard purification and counting were then performed. Small aliquots of $\mathrm{CO}_{2}$ were collected for measurements of $\delta^{18} \mathrm{O}$ and $\delta^{13} \mathrm{C}$. Insoluble organic residue was washed in distilled water until neutral, dried in an electric oven, and, if the amount of organic matter was sufficient, charred in a stream of nitrogen and combusted to obtain $\mathrm{CO}_{2}$ for age measurement.

The results of ${ }^{14} \mathrm{C}$ age measurements of all tufa samples and associated organic matter are listed in Table 1 together with the corresponding values 
of $\delta^{13} \mathrm{C}$ and $\delta^{18} \mathrm{O}$. Measurements of $\delta^{13} \mathrm{C}$ and $\delta^{18} \mathrm{O}$ were performed at the Mass Spectrometry Laboratory of the Maria Curie Skłodowska University in Lublin using the mass spectrometer MI $1305 .{ }^{14} \mathrm{C}$ ages of the carbonate fraction $\left(\mathrm{T}_{\mathrm{C}}\right)$ of tufa samples were calculated assuming initial ${ }^{14} \mathrm{C}$ activity $\mathrm{A}_{\mathrm{O}}=100 \mathrm{pmc}$ (per cent of modern carbon). All ${ }^{14} \mathrm{C}$ dates on carbonate $\left(\mathrm{T}_{\mathrm{C}}\right)$ and organic $\left(\mathrm{T}_{\mathrm{ORG}}\right)$ fractions were normalized to $\delta^{13} \mathrm{C}=-25 \%$ ws $\mathrm{PDB}$

TABLE 1

Results of radiocarbon age determinations and ${ }^{13} \mathrm{C}$ and ${ }^{18} \mathrm{O}$ measurements in tufa samples

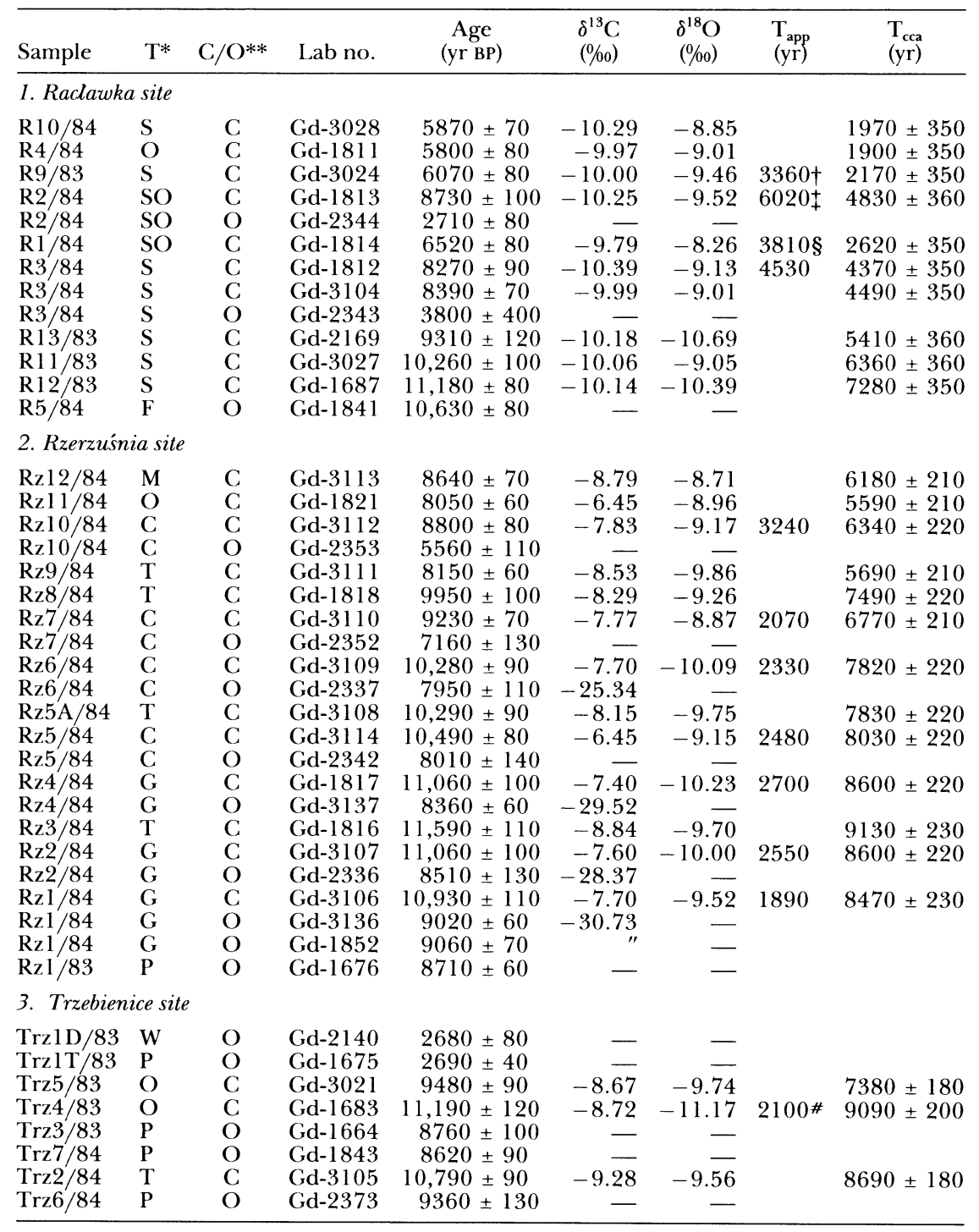


TABLE 1 (continued)

\begin{tabular}{|c|c|c|c|c|c|c|c|c|}
\hline Sample & $\mathrm{T}^{*}$ & $\mathrm{C} / \mathrm{O} * *$ & Lab no. & $\begin{array}{c}\text { Age } \\
(\mathrm{yr} \text { BP) }\end{array}$ & $\begin{array}{l}\delta^{13} \mathrm{C} \\
(\% 0)\end{array}$ & $\begin{array}{c}\delta^{18} \mathrm{O} \\
(\% 0)\end{array}$ & $\begin{array}{l}\mathrm{T}_{\text {app }} \\
(\mathrm{yr})\end{array}$ & $\begin{array}{l}\mathrm{T}_{\text {cca }} \\
(\mathrm{yr})\end{array}$ \\
\hline \multicolumn{9}{|c|}{ 4. Sieradowice site } \\
\hline S3T & $\mathrm{H}$ & $\mathrm{O}$ & Gd-1572 & $4870 \pm 70$ & - & - & & \\
\hline S3/68 & G & $\mathrm{C}$ & Gd-1715 & $6030 \pm 70$ & -7.03 & -10.08 & 930 & $5120 \pm 140$ \\
\hline $\mathrm{S} 3 / 68$ & $G$ & $\mathrm{O}$ & Gd-1718 & $5100 \pm 80$ & -28.40 & & & \\
\hline $\mathrm{S} 3 / 158$ & $\mathrm{G}$ & $\mathrm{C}$ & Gd-3042 & $8150 \pm 60$ & -7.90 & -9.55 & 1040 & $7240 \pm 130$ \\
\hline $\mathrm{S} 3 / 158$ & G & $\mathrm{O}$ & Gd-2199 & $7110 \pm 160$ & -28.30 & & & \\
\hline $\mathrm{S} 3 / 310$ & G & $\mathrm{C}$ & Gd-2197 & $8560 \pm 120$ & -8.50 & -9.67 & 480 & $7650 \pm 170$ \\
\hline $\mathrm{S} 3 / 310$ & G & $\mathrm{O}$ & Gd-3045 & $8080 \pm 80$ & -28.70 & & & \\
\hline $\mathrm{S} 3 / 457$ & $\mathrm{C}$ & C & Gd-1716 & $9890 \pm 80$ & -8.98 & -9.22 & 1220 & $8980 \pm 140$ \\
\hline $\mathrm{S} 3 / 457$ & $\mathrm{C}$ & $\mathrm{O}$ & Gd-2200 & $8670 \pm 110$ & -28.10 & & & \\
\hline $\mathrm{S} 3 / 550$ & G & $\mathrm{C}$ & Gd-3043 & $10,480 \pm 70$ & -9.40 & -11.42 & 880 & $9570 \pm 140$ \\
\hline $\mathrm{S} 3 / 550$ & G & $\mathrm{O}$ & Gd-1 722 & $9600 \pm 80$ & -28.6 & - & & \\
\hline S3B & $\mathrm{H}$ & $\mathrm{O}$ & Gd-2056 & $9630 \pm 100$ & - & - & & \\
\hline S3A & W & $\mathrm{O}$ & Gd- 1574 & $9680 \pm 60$ & - & - & & \\
\hline S1A & W & $\mathrm{O}$ & Gd-2057 & $11,360 \pm 220$ & - & - & & \\
\hline S7/115 & $\mathrm{G}$ & $\mathrm{C}$ & Gd-3238 & $6550 \pm 40$ & -8.12 & -8.93 & & $5640 \pm 130$ \\
\hline $\mathrm{S} 7 / 130$ & $G$ & $\mathrm{C}$ & Gd-3239 & $6750 \pm 50$ & -8.00 & -8.71 & & $5840 \pm 130$ \\
\hline $\mathrm{S} 7 / 170$ & G & C & Gd-1959 & $7110 \pm 90$ & -7.97 & -10.39 & & $6200 \pm 150$ \\
\hline $\mathrm{S} 7 / 260$ & C & $\mathrm{C}$ & Gd-3240 & $8160 \pm 80$ & -9.00 & -11.15 & & $7250 \pm 150$ \\
\hline $\mathrm{S} 7 / 330$ & G & C. & & & -9.15 & -10.38 & & \\
\hline $\mathrm{S} 7 / 410$ & C & C & Gd-1962 & $9510 \pm 90$ & -8.70 & -10.24 & & $8600 \pm 150$ \\
\hline $\mathrm{S} 7 / 525$ & G & C & Gd-2485 & $10,020 \pm 130$ & -9.35 & -10.39 & & $9110 \pm 180$ \\
\hline $\mathrm{S} 7 / 605$ & $\mathrm{G}$ & C & Gd-3246 & $10,230 \pm 90$ & -9.82 & -10.85 & & $9320 \pm 150$ \\
\hline \multicolumn{9}{|c|}{ 5. Gliczarów site } \\
\hline G1-Ic & $\mathrm{P}$ & $\mathrm{O}$ & Gd-1644 & $1730 \pm 50$ & - & - & & \\
\hline G1-Ic & $\mathrm{P}$ & $\mathrm{O}$ & Gd-1651 & $1610 \pm 60$ & - & - & & \\
\hline Gl-Id & $\mathrm{M}$ & C & Gd-1680 & $14,530 \pm 150$ & -7.39 & -9.93 & & \\
\hline Gl-Id & $\mathrm{M}$ & $\mathrm{O}$ & Gd-2223 & $1210 \pm 180$ & & & & \\
\hline G11/83 & $\mathbf{M}$ & $\mathrm{C}$ & Gd-3054 & $19,680 \pm 210$ & -2.76 & -8.89 & & \\
\hline G12/83 & $\mathrm{S}$ & $\mathrm{C}$ & Gd-3053 & $15,290 \pm 130$ & -5.56 & -10.85 & & \\
\hline G115/83 & M & $\mathrm{C}$ & Gd-3055 & $17,490 \pm 120$ & -2.67 & -8.95 & & \\
\hline
\end{tabular}

* Type of deposit: $\mathrm{G}$-gyttja, $\mathrm{C}$-calcareous mud, S-stromatolite, $\mathrm{O}$-oncoids, $\mathrm{M}$-moss travertine, $\mathrm{T}$ - tufa, $\mathrm{P}$ - peat, $\mathrm{F}$ - fossil soil, $\mathrm{H}$ - -humus, $\mathrm{W}$ - wood ** $\mathrm{O}$-organic fraction, $\mathrm{C}$ - carbonate fraction

$+\mathrm{T}_{\mathrm{app}}$ estimated by comparison with organic fraction age of underlying sample $\mathrm{R} 2 / 84$ + Redeposited oncoids (see text); quoted value does not enter in calculation of mean value of $\mathrm{T}_{\mathrm{app}}$ $\mathrm{R} 2 / 84$

$\S$ Estimated by comparison of $T_{C}$ with age of organic fraction of overlying sample \# Estimated by comparison with two dates on peat samples (Trz3/83 and Trz7/84)

using either measured or estimated values of $\delta^{13} \mathrm{C}$, according to the recommendations of Stuiver and Polach (1977).

Because the actual value of $A_{O}$ in the carbonate fraction of tufa is always $<100$ pmc (usually, 50 pmc $<$ Ao $<95$ pmc, $c f$ Pazdur \& Pazdur, 1986; A Pazdur, $m$ in preparation), the value of $\mathrm{T}_{\mathrm{C}}$ calculated under the assumption $A_{O}=100$ pmc is greater than the true age $T$. The resulting difference is known as the reservoir effect, and to account for it we must estimate either the actual value of $\mathrm{A}_{\mathrm{O}}$, or the corresponding aging of tufa at the moment of deposition. This aging, which may be called initial apparent age, is related to $\mathrm{A}_{\mathrm{O}}$ through equation

$$
\mathrm{T}_{\mathrm{app}}=-8033 \ln \mathrm{A}_{\mathrm{O}} .
$$




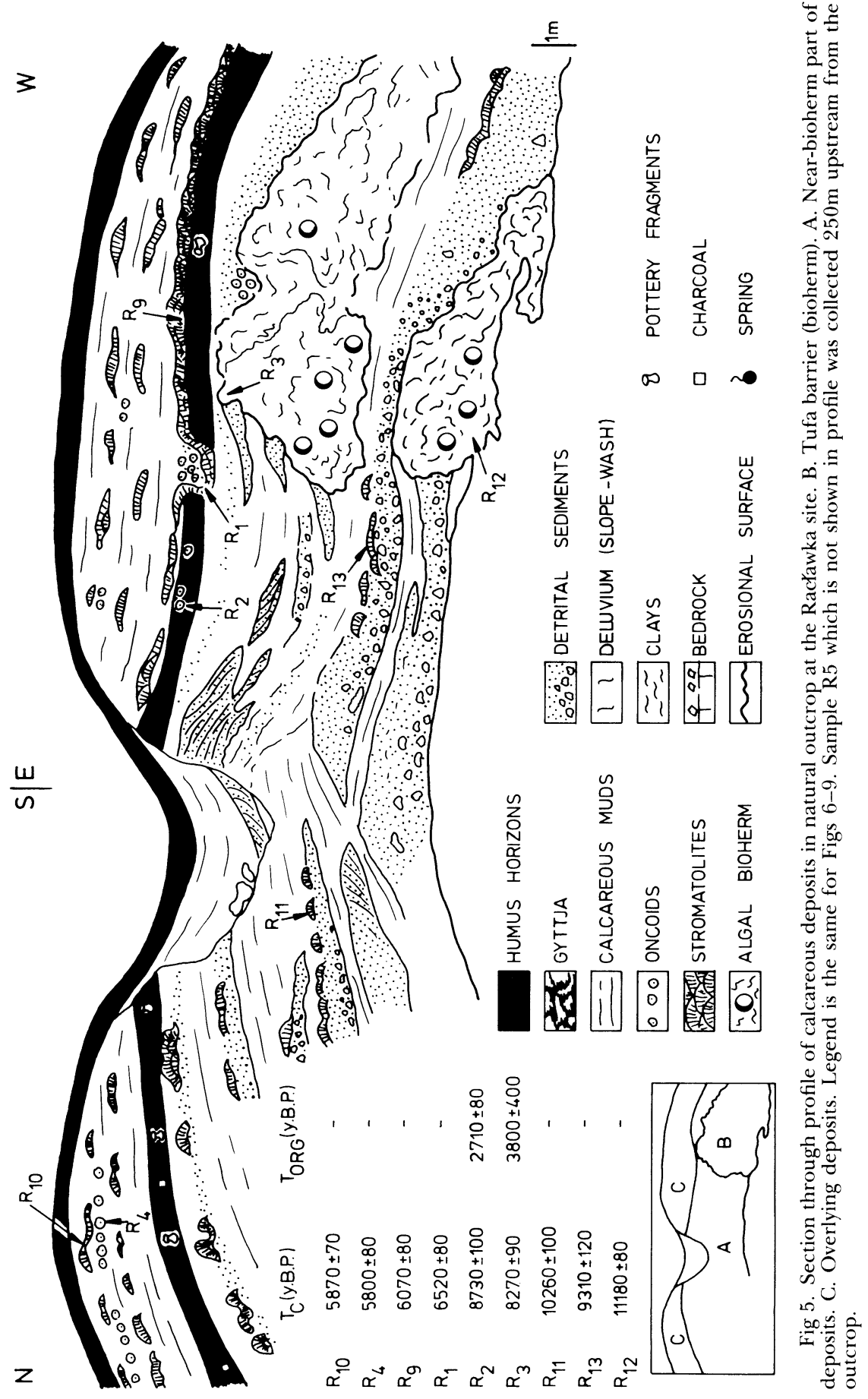


Assuming that: 1) the carbonate and organic matter were deposited simultaneously, 2) ${ }^{14} \mathrm{C}$ content in both carbonate and organic matter was changing in the past only due to radioactive decay, and 3) organics in carbonate matrix are remnants of land vegetation, the initial value of apparent age of an individual sample can be determined from actually measured ages of carbonate and associated organics

$$
\mathrm{T}_{\mathrm{app}}=\mathrm{T}_{\mathrm{C}}-\mathrm{T}_{\mathrm{ORG}} .
$$

The validity of the last assumption is justified by paleobotanical analyses of selected levels and also by measured values of $\delta^{13} \mathrm{C}$ in some organic fractions. The values of $\delta^{13} \mathrm{C}$, quoted in Table 1 , range from $-25 \%$ to $-31 \% 0$ in the Rzerzuśnia profile, while in Sieradowice, they are close to $-28.5 \%$, $i e$, they are typical for remnants of land vegetation ( $c f$ Stuiver \& Polach, 1977, Fig 1, p 358). Corrected carbonate ages $\left(\mathrm{T}_{\text {cca }}\right)$ appear in Table 1 and are defined as

$$
\mathrm{T}_{\text {cca }}=\mathrm{T}_{\mathrm{C}}-\left\langle\mathrm{T}_{\mathrm{app}}\right\rangle,
$$

where $\left\langle\mathrm{T}_{\text {app }}\right\rangle$ denotes mean value of the apparent age in the profile.

\section{SITE DESCRIPTIONS}

\section{Racławka}

The ravine of the Racławka stream is incised in Lower Carboniferous limestones and is filled mainly with different types of tufa deposits. The Rackawka stream is the largest of those investigated. Its descent is so great that the stream has features typical of turbulent mountain streams. Type and development of deposits of the Racławka valley indicate that the stream probably had the same hydrodynamic features during the time of tufa deposition as now. Our studies were performed on an outcrop (Fig 5), where three different areas can be distinguished, namely: the bioherm (B), with its close surroundings (A) and the overlying deposits (C). In this profile, as well as in the whole valley, sediments of strong and turbulent water flow dominate, consisting of bioherm structures, stromatolites, oncoids, and coarse-grained detritic deposits. Sedimentologic studies of Szulc $(1984,1986)$ have shown that the bioherm is built of algal fabrics of Cladophora and Vaucheria in the lower part, and Cyanophyta (Rivularia, Homeothrix, and mostly Phormidium) in the upper part.

This structure experienced very fast vertical development, induced by concurrent processes of $\mathrm{CaCO}_{3}$ precipitation and a tendency for algae to escape cementation. This fast vertical development caused a formation of the tufa barrier and a shallow, stagnant-water basin with relatively calm conditions of deposition (the near-bioherm part of the outcrop (A) in Fig 5). During a period of erosion, the bioherm was truncated and covered with coarse detritic material. During the next period of conditions more favorable for tufa sedimentation, accumulation occurred on its upper part. While the growth of the tufa barrier was declining, the stagnant-water basin 
was filled, hydrodynamic conditions became uniform, and the overlying series (C in Fig 5) was deposited.

\section{Results}

In the investigated outcrop, the bedrock-sediment contact is not visible, though ca $250 \mathrm{~m}$ upstream a late glacial fossil soil was found and dated at $10,630 \pm 80 \mathrm{BP}: \mathrm{Gd}-1841$. The soil was developed immediately upon the rock basement and overlain with tufas which may be correlated with the series seen at the outcrop. Samples for ${ }^{14} \mathrm{C}$ dating were collected from the three parts of the profile, ie, from the tufa barrier (samples R3 and R12), from its close surroundings (samples R11 and R13) and from overlying deposits (samples R1, R2, R4, R9, and R10). All samples but two (R2 and R3) contained too little organic matter for ${ }^{14} \mathrm{C}$ age determination with our large proportional counters. The value of the apparent age estimated from measured values of $T_{C}$ and $T_{O R G}$ in sample $R 3$ is equal to $4530 \pm 410 \mathrm{yr}$. In the second sample (R2), the organic fraction was taken from the humus level developed on tufa layer consisting mostly of oncoids. ${ }^{1}$ A large discrepancy between $T_{C}$ and $T_{O R G}$ obtained on this sample may be caused by redeposition of the oncoids. Detailed sedimentologic analyses of this part of the profile have shown evidence of redeposition dated oncoids and the presence of undoubtedly reworked tufas of other types. The high value of $T_{\text {app }}$ obtained on sample R2 and the inversion of dates of carbonate fraction of samples R2 and R3 could be explained then by redeposition of older tufaceous sediments. By comparing $\mathrm{T}_{\mathrm{ORG}}(\mathrm{R} 2)$ with $\mathrm{T}_{\mathrm{C}}(\mathrm{R} 1)$ and $\mathrm{T}_{\mathrm{C}}(\mathrm{R} 9)$, we obtained two values of apparent age, equal respectively to 3360 and 3810 yr. As those values were calculated from ${ }^{14} \mathrm{C}$ dates of stromatolites above and below the soil level (sample R2), the first value of $\mathrm{T}_{\text {app }}$ should be lower, and the second one higher than the true value of $T_{\text {app }}$. Thus, it seems reasonable to calculate the value of the apparent age of tufa sediments in the Racławka site as the mean of three quoted values, $3900 \pm 340 \mathrm{yr}$.

\section{Rzerzuśnia}

Tufaceous sediments in the Rzerzuśnia site fill the floor of a wide valley cut into Oxfordian limestones and Senonian marls. The basal sediments are calcareous gyttja. High concentrations of $\mathrm{H}_{2} \mathrm{~S}$ in this series indicates rather fast isolation of the organic layer and decomposition in a reducing environment.

The profile shown in Figure 6 is clearly bipartite; its lower part (up to sample Rz9) is composed of fine-grained calcareous muds deposited in lowenergy water flow, with the exception of layer Rz5-Rz6, which contains reworked tufa sands deposited probably during a single extreme flood. The sediments occurring above the level Rz9 are typical of fast, turbulent water flow and consist of oncoids and stromatolites. The entire series is overlain with loessy colluvium.

\footnotetext{
${ }^{1}$ Sample from the upper part of this soil horizon was previously dated by M A Geyh, Hannover, FRG (2475 $\pm 60: \mathrm{Hv}-9705)$.
} 


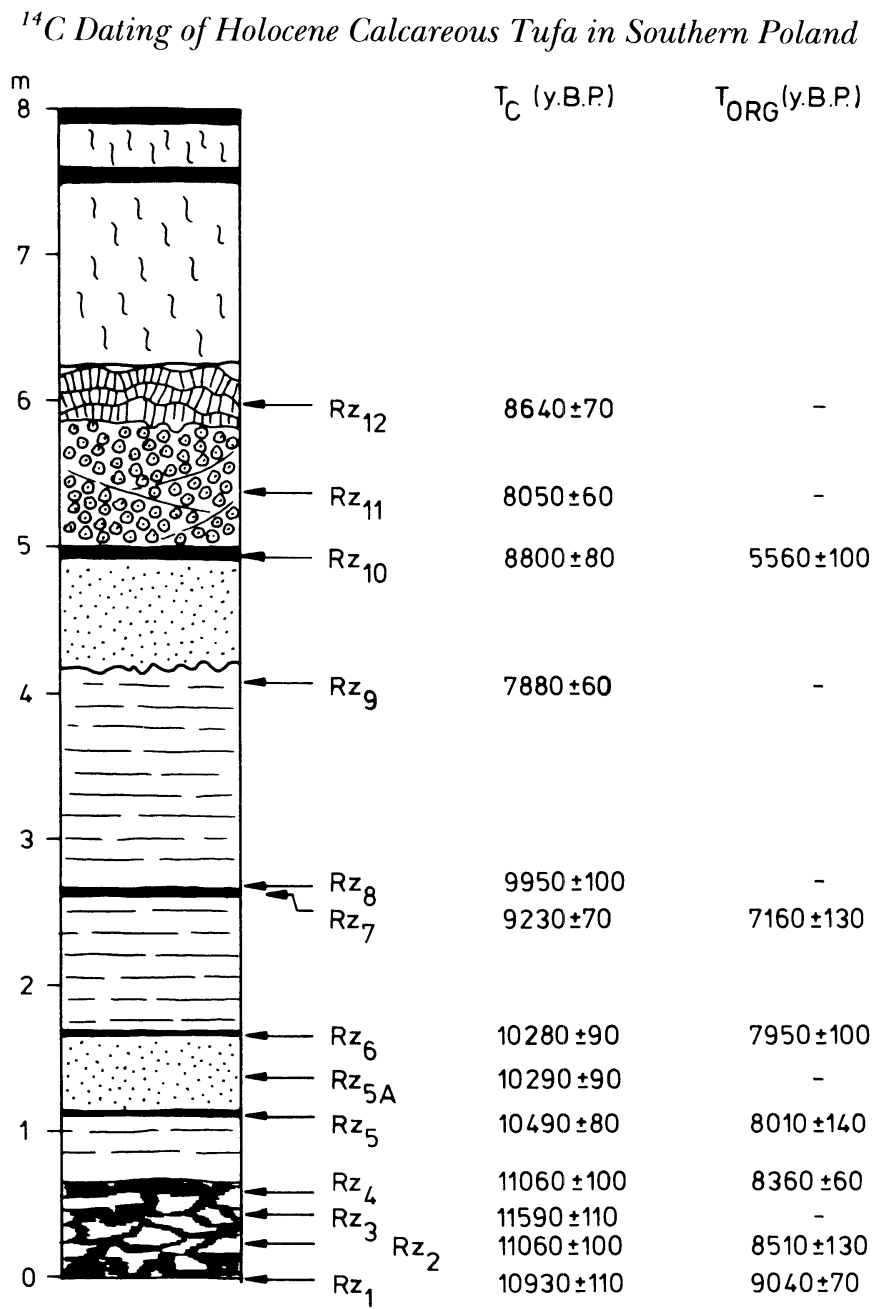

Fig 6. Cross-section of deposits in the Rzerzuśnia site. Only samples collected in 1984 are shown in the profile. For sample Rzl the mean value of two independent determinations of $\mathrm{T}_{\mathrm{ORG}}$ is quoted (see Table 1). Sample Rzl/83 (see Table 1) was collected in 1983 from ca $20 \mathrm{~cm}$ thick base of the organic series. See Fig 5 and text.

\section{Results}

Measurements of $\mathrm{T}_{\text {app }}$ were possible on seven samples from different parts of the profile, thus enabling precise determination of the apparent age. The values of apparent age obtained on single samples scatter around a mean value of $2460 \pm 200 \mathrm{yr}$. A significantly higher value of $\mathrm{T}_{\text {app }}$ obtained on sample Rz 10 may be explained by redeposition, although it was included in calculation of the mean value $\left\langle\mathrm{T}_{\mathrm{app}}\right\rangle$. The values of $\mathrm{T}_{\mathrm{C}}$ in the profile show four significant inversions between successive samples ( $\mathrm{Rz} 2 / \mathrm{Rz} 3, \mathrm{Rz} 7 / \mathrm{Rz} 8$, $\mathrm{Rz} 9 / \mathrm{Rz} 10$, and Rz11/Rz12). The inversions of samples $\mathrm{Rz} 9 / \mathrm{Rz} 10$ are caused by redeposition of Rz10; the others may be caused by dissolution and reprecipitation of $\mathrm{CaCO}_{3}$ in the vadose zone of ground water, resulting 


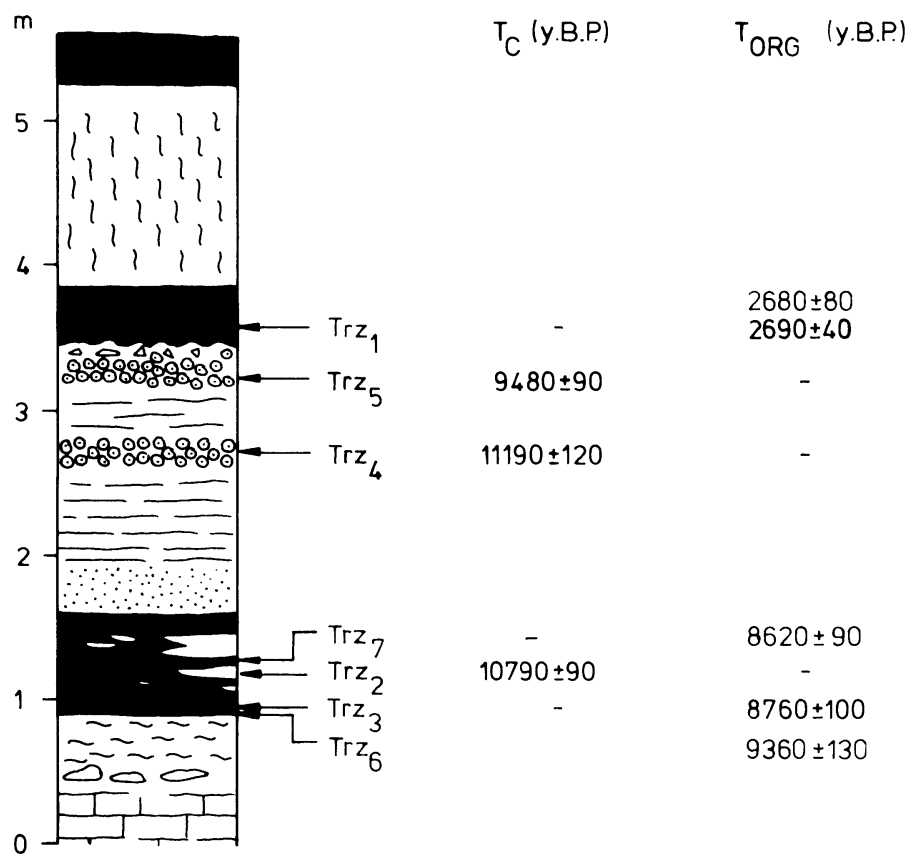

Fig 7. Cross-section through deposits of the Trzebienice site.

in the formation of secondary cementation levels. Evidence for this is seen in the profile layers enriched in iron hydroxides, marking the position of former piezometric levels.

\section{Trzebienice}

Sediments found in this profile (Fig 7) were deposited in similar geologic and hydrodynamic conditions as those in the previous site. The sequence of sedimentation is similar to that at the Rzerzuśnia site. The sediments start with a level of peaty deposits overlain with a series of calcareous muds at the lower part and oncoids in the upper part, thus indicating increased energy of water flow. There is evidence of erosion at the topmost layer of the tufa sediments. The calcareous series is overlain with peat and covered by loessy colluvium.

\section{Results}

Simultaneous determination of the age of both carbonate and organic fractions was not possible in this profile, but a comparison of the ${ }^{14} \mathrm{C}$ age of carbonate from a lenticel of tufa embedded within a peat layer with two ${ }^{14} \mathrm{C}$ dates from over- and underlying peat, yielded the value of $\mathrm{T}_{\text {app }}$ equal to $2100 \pm 160 \mathrm{yr}, i e$, very close to that found in the Rzerzuśnia profile. There is no clear relation between ${ }^{14} \mathrm{C}$ dates of samples Trz 5 and Trz1 because of a hiatus in the profile caused by erosion. 


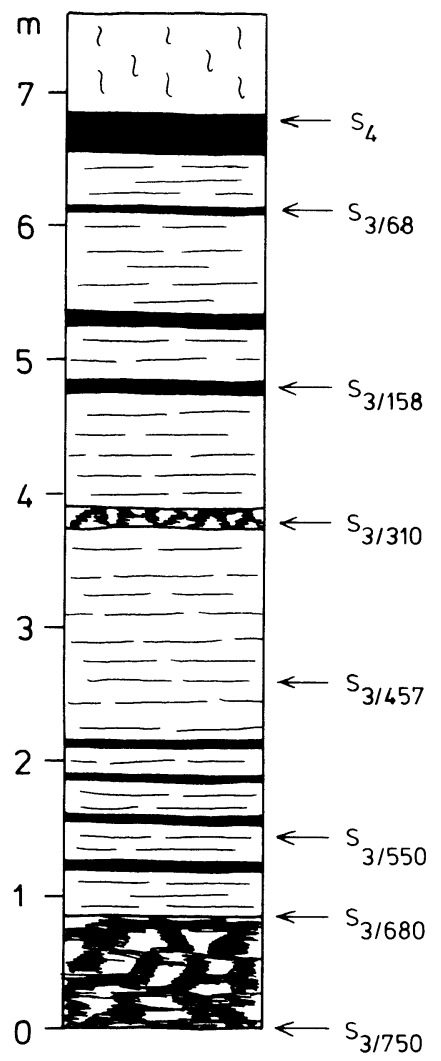

\begin{tabular}{|c|c|}
\hline${ }_{C}{ }_{C}(y \cdot B P)$ & ${ }_{\text {ORG }}{ }^{\text {y. BP }}$ \\
\hline - & $4870 \pm 70$ \\
\hline $6030 \pm 90$ & $5100 \pm 90$ \\
\hline $8150 \pm 60$ & $7110 \pm 160$ \\
\hline $8560 \pm 120$ & $8080 \pm 80$ \\
\hline $9890 \pm 80$ & $8670 \pm 110$ \\
\hline $10480 \pm 70$ & $9600 \pm 80$ \\
\hline - & $9680 \pm 60$ \\
\hline & $9630 \pm 100$ \\
\hline & 50 \\
\hline
\end{tabular}

Fig 8. Cross-section of deposits in the Sieradowice site, profile S3 (after Jersak et al, 1983, partly changed). The profile S7 represents quite similar lithologic sequence as S3.

\section{Sieradowice}

Calcareous sediments of the flat valley at the Sieradowice site (Holy Cross Mts) differ significantly from those found at other sites, mostly due to their uniformity (Fig 8). Overlying the Devonian limestones and marls is calcareous gyttja with numerous wood fragments, overlain with peaty bog soil, then calcareous muds with several thin layers enriched in organic matter. Near the top of the $5 \mathrm{~m}$ thick tufaceous deposits is a younger bog soil overlain with loessy colluvium. The sediments of the Sieradowice site represent carbonate deposition in an extremely low energy water flow, in conditions similar to limnic sedimentation.

\section{Results}

The value of apparent age was determined by comparing ${ }^{14} \mathrm{C}$ dates of carbonate and organic fractions in five samples collected from levels enriched in organic matter, situated in different parts of the profile S3. The 
NE

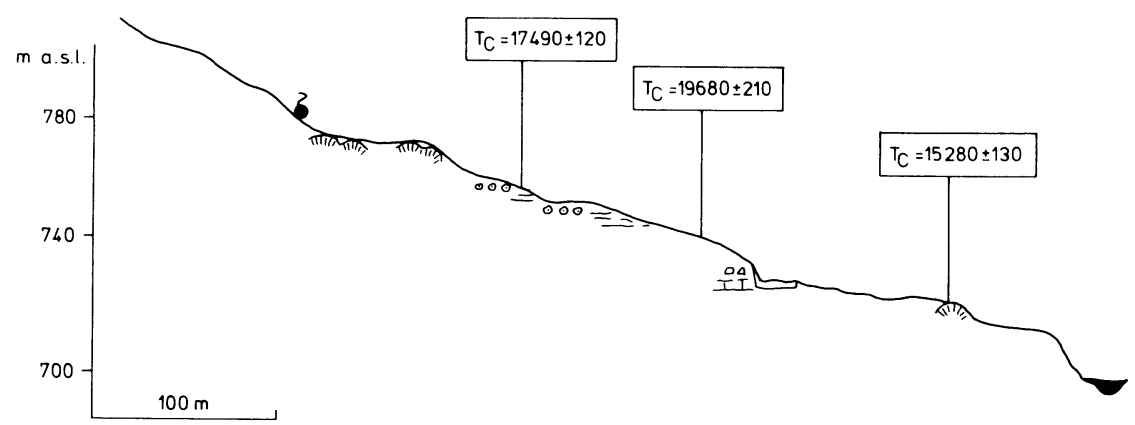

Fig 9. Cross-section of deposits in the Gilczarów site.

mean value of $\mathrm{T}_{\text {app }}$ is equal to $910 \pm 120 \mathrm{yr}$. No age inversions were found in both dated profiles S3 and S7.

\section{Gliczarów}

In this site, tufas were deposited from deep underground water, as indicated by elevated sulphur content, at springs of tectonic origin, and occur in the form of a non-uniform cover ca 1 to $2 \mathrm{~m}$ thick and $60 \mathrm{~m}$ long on a valley slope (Fig 9). Various types of tufa are present, mostly moss travertines, stromatolites, and diagenetically altered calcareous muds. The degree of lithification decreases uphill, and at the topmost part of the valley slope, mostly pure, abiogenic near-spring travertines are deposited.

\section{Results}

Four samples were dated, none of which contained enough organic matter for even a rough estimate of the apparent age. Obtained values of $\mathrm{T}_{\mathrm{C}}$ and $\delta^{13} \mathrm{C}$, which are significantly higher than the corresponding values in any other investigated site, indicate the distinct features of tufas of the Gliczarów site. The true age of these tufas is unknown, the geologic and paleontologic age estimates are not equivocal. Based on the paleontologic studies of Halicki and Lilpop (1932) and Urbanski (1932), the tufas are of Pleistocene age. On the contrary, malacologic studies lead Alexandrowicz (1985) to the conclusion that the tufas at Gliczarów represent the boundary of late glacial and Holocene. Samples denoted as Gl-I (see Table 1) were dated to determine the end of tufa deposition at this site. The results (Table 1) indicate that there is no clear relation between tufa deposition and the growth of the peat layer.

\section{DISCUSSION OF THE RESULTS}

The reliability of ${ }^{14} \mathrm{C}$ dates on tufaceous deposits is determined by a number of factors which may be of either primary or secondary origin. Primary factors are connected with fractionation of carbon iosotopes in the sedimentation process and determine the initial ${ }^{14} \mathrm{C}$ concentration of carbonates. Thus, an accurate estimate of the true value of $A_{O}$ is of primary 
importance for reliable dating of tufaceous deposits. Unfortunately, until now very little has been known about the possible variations of the initial ${ }^{14} \mathrm{C}$ activity in tufas, though much work has been devoted to the ${ }^{14} \mathrm{C}$ concentration in bicarbonates dissolved in water (see eg, Mook, 1980). As was proved (Srdoc et al, 1983; Krajcar et al, 1985) the ${ }^{14} \mathrm{C}$ activity of dissolved inorganic carbon (DIC) in groundwaters changes in both space and time as a result of the exchange of DIC with atmospheric and soil $\mathrm{CO}_{2}$ of high ${ }^{14} \mathrm{C}$ concentration. Srdoc et al (1983) found values of $\mathrm{A}_{\mathrm{O}}$ equal to ca $60 \mathrm{pmc}$ in spring water and $>90 \mathrm{pmc}$ in river water. Similar conclusions are drawn by Thorpe, Otlet and Sweeting (1980). This downstream enrichment is facilitated by increasing turbulence of water flow.

The highly complicated nature of physical, chemical, and biologic mechanisms involved in precipitation of $\mathrm{CaCO}_{3}$ from DIC to form tufaceous deposits, leads to serious difficulties in the application of well-known models used in ${ }^{14} \mathrm{C}$ dating of groundwaters to dating of tufas. For example, Srdoc et al $(1980,1983)$ estimated certain values of $A_{O}$ for tufas from the Croatian Karst, but for all samples they assume a value of $A_{O}$ equal to 85 pmc.

Our results indicate the connection of apparent age $\mathrm{T}_{\text {app }}$ (or the corresponding value of initial ${ }^{14} \mathrm{C}$ activity, $\mathrm{A}_{\mathrm{O}}$ ) with the environment of tufa deposition. In streams with turbulent and fast flow, tufaceous sediments show the highest values of $\mathrm{T}_{\text {app }}$ (ca $4000 \mathrm{yr}$ in the Racławka site). Deposits of streams with moderate and variable flow show lower values of $\mathrm{T}_{\text {app }}$ (ca 2500 $\mathrm{yr}$ in the Rzerzuśnia site and ca $2100 \mathrm{yr}$ in the Trzebienice site), while stagnant water deposits have the lowest value $(<1000 \mathrm{yr}$, the Sieradowice site). It seems that similar features could be observed along a single river course in the analysis of $\mathrm{T}_{\text {app }}$ of tufas deposited at different energetic zones of the river. The dependence of $T_{\text {app }}$ upon the turbulence of water flow can be seen even in the microscale of a single site. For example, stromatolites overlying layers with oncoids have greater values of $T_{C}$ than the oncoids themselves (samples R10 and R4 from the Racławka site, Rz12 and Rz11 from the Rzerzuśnia site). Therefore, systematic studies of the relation between $\mathrm{T}_{\text {app }}\left(\right.$ or $\mathrm{A}_{\mathrm{O}}$ ) and the hydrodynamic conditions of tufa sedimentation (and, consequently, the type of tufa) should contribute to more effective application of the ${ }^{14} \mathrm{C}$ method of dating calcareous tufa.

Secondary factors influencing the reliability of ${ }^{14} \mathrm{C}$ dates of tufaceous deposits include redeposition and diagenetic changes. Redeposition of tufas is sometimes difficult to recognize, especially in the case of finegrained muds and oncoids ( $c f$ samples R2 and Rz10). Dating of redeposited material leads to erroneously older ${ }^{14} \mathrm{C}$ dates. Detailed geologic examination of the profile may, in most cases, exclude this type of error. Postdepositional changes of tufa deposits consist of dissolution and reprecipitation of $\mathrm{CaCO}_{3}$ within the sediment, or precipitation in primary interstices. Both processes of cementation lead to contamination of primary $\mathrm{CaCO}_{3}$ with ${ }^{14} \mathrm{C}$ contained in percolating water, and, as a rule, cause rejuvenation of ${ }^{14} \mathrm{C}$ dates ( $c f$ sample Rz7). As the process of cementation is not simple and may repeat several times during the geologic history of the sediment, the possibility of obtaining older ${ }^{14} \mathrm{C}$ dates cannot be excluded. 
SEDIMENTATION RATE OF TUFACEOUS DEPOSITS

Sedimentologic analysis and ${ }^{14} \mathrm{C}$ dating enables us to estimate the sedimentation rate of different types of tufa deposits. In the Rzerzuśnia site, organogenic sediments were deposited with the rate equal to $1 \mathrm{~cm} / 10 \mathrm{yr}$ (samples Rz1-Rz4), while calcareous muds with rate $1 \mathrm{~cm} / 8$ yr (samples Rz6Rz7). Redeposited sediments of ca $0.5 \mathrm{~m}$ total thickness (samples Rz5-Rz6) are associated with increased discharge over an interval of $<100 \mathrm{yr}$, but they probably represent deposits of a single extreme flood. The highest sedimentation rate, with distinct variability of seasonal increments, is associated with stromatolites. This makes it possible, in certain cases, to distinguish and count yearly increments ("varves") of such deposits. The value of ca $10 \mathrm{~mm} / \mathrm{yr}$ was found for stromatolite R9 from the Racławka site (Fig 5), the upper part of the tufa barrier (B in Fig 5) was deposited with a rate of at least $4 \mathrm{~mm} / \mathrm{yr}$, as deduced from ${ }^{14} \mathrm{C}$ dates of samples R13 and R3. Similar values of yearly increments were found by Monty (1976) for recent stromatolites from the Houyoux stream in Belgium. The sedimentation rate of calcareous muds in the Sieradowice site is similar in both dated profiles and reveals systematic decrease from ca $2.5 \mathrm{~mm} / \mathrm{yr}$ at the basal part (ca $9500 \mathrm{BP}$ ) to $1 \mathrm{~mm} / \mathrm{yr}$ at the topmost part (ca $5000 \mathrm{BP}$ ).

\section{CONCLUSIONS}

Processes of isotopic differentiation that occur during sedimentation of calcareous tufa and lead to different initial values of ${ }^{14} \mathrm{C}$ concentration depend on the lithologic type of tufa. Estimated values of initial ${ }^{14} \mathrm{C}$ concentration range from 62 pmc in oncoids and stromatolites from Racławka to $89 \mathrm{pmc}$ in calcareous muds from Sieradowice. Corresponding values of initial apparent age range from 3900 to $910 \mathrm{yr}$. Therefore, reliable ${ }^{14} \mathrm{C}$ dating of tufaceous sediments strictly depends on correct classification of lithologic types of samples collected for dating.

Estimating real age of individual layers in a studied tufa profile is relatively easy even when few organic levels, deposited simultaneously with tufa, can be found. A constant value of $\delta^{13} \mathrm{C}$ in a profile may indicate the consistency of initial apparent age of individual tufa layers in the investigated profile.

Individual types of tufaceous sediments reveal different susceptibility to redeposition and diagenesis. These processes may change both the ${ }^{14} \mathrm{C}$ concentration and the ${ }^{13} \mathrm{C}$ and ${ }^{18} \mathrm{O}$ content of tufa. Thus, careful selection of samples, including microscopic examination is recommended. Observed differences of $\delta^{13} \mathrm{C}$ in investigated types of tufaceous sediments, ranging from $-12 \%$ in tufas from Racławka, to $-2.5 \%$ in stromatolites from Gliczarów, indicate the necessity of measuring $\delta^{13} \mathrm{C}$ of all dated samples.

\section{ACKNOWLEDGMENTS}

This study was carried out with significant financial support from the Central Research Project CPBP 03.13 to the Radiocarbon Laboratory in Gliwice. Tufa samples from the Sieradowice site were collected and submit- 
ted by Zbigniew Snieszko, Silesian University, Sosnowiec. All $\delta^{13} \mathrm{C}$ and $\delta^{18} \mathrm{O}$ measurements were carried out by Romuald Awsiuk. Radiocarbon Laboratory, under the kind supervision of Stanisław Hałas, Institute of Physics, Maria Curie Skłodowska University, Lublin, to whom the authors are gratefully indebted. Special thanks are due all colleagues from the Radiocarbon Laboratory, especially Tomasz Goslar and technicians Helena Skorupka and Władysław Lipian, for their great help in laboratory work.

\section{REFERENCES}

Alexandrowicz, S W, 1983, Malacofauna of Holocene calcareous sediments of Cracow Upland: Acta Geol Polonica, v 33, p 117-158.

1985, Malacofauna of the Holocene calcareous tufa from Podhale and Pieniny Mts, in Carpatho-Balkan Assoc Cong, 13th, Proc: Geol Inst, Cracow, p 7-10.

Buccino, G, D’Argenio, B, Ferreri, V, Brancaccio, L, Ferreri, M, Panichi, C and Stanzione, D, 1978, I travertini della Bassa Valle Del Tanagro (Campania): Studio geomorfologico, sedimentologico et geochimico: Soc Geol Italiana Boll, v 97, p 617-646.

D'Argenio, B, Ferreri, V, Stanzione, D, Brancaccio, L and Ferreri, M, 1983, I travertini di Pontecagnano (Campagna): Geomorfologia, sedimentologia, geochimica: Soc Geol Italiana Boll, v 102, p 123-136.

Demovic, R, Hoefs, J and Wedepohl, K H, 1972, Geochimische Untersuchungen an Travertinen der Slovakei: Contr Mineral \& Petrol, v 31, p 15-38.

Friedman, I, 1970, Some investigations of the deposition of travertine from hot springs. I. The isotopic chemistry of a travertine depositing spring: Geochim et Cosmochim Acta, v 34, p 1303-1315.

Gonfiantini, R, Panichi, C and Tongiorgi, E, 1968, Isotopic disequilibrium in travertine deposition: Earth Planetary Sci Letters, v 5, p 55-58.

Halicki, B and Lilpop, J, 1932, Czwartorzedowe trawertyny w Gliczarowie na Podhalu: Posiedzenia Naukowe Panstowowego Inst Geol, p 97-98.

Jersak, J, Klatka, T and Snieszko, Z, 1983, Poznovistulianskie i holocenskie osady w rejonie Sieradowic (Gory Swietokrzyskie), in Poznovistulianskie i holocenskie zmiany srodowiska geograficznego na obszarach lessowych, Przewodnik konf: Univ Slaski, Katowice, p 84-92.

Krajcar, I, Horvatincic, N, Srdoc, D and Obelic, B, 1985, On the initial ${ }^{14} \mathrm{C}$ activity in karst aquifers with short mean residence time, in Internatl ${ }^{14} \mathrm{C}$ conf, 12 th, Abs: Trondheim, Tapir, p 154.

Manfra, L, Masi, U and Turi, B, 1976, La composizione isotopica dei travertini del Lazio: Geol Romana, v 15, p 127-174.

Monty, C L V, 1976, The origin and development of cryptalgal fabrics, in Walter, M R, ed, Developments in sedimentology, vol 26, Stromatolites:Amsterdam, Elsevier, p 193-259.

Mook, W G, 1980, Carbon-14 in hydrogeological studies, in Fritz, P and Fontes, J Ch, eds, Handbook of environmental isotope geochemistry, vol 1, The terrestial environment:Amsterdam, Elsevier, p 49-74.

Pazdur, A and Pazdur, M F, 1986, ${ }^{14} \mathrm{C}$ dating of calcareous tufa from different environments, in Stuiver, $\mathrm{M}$ and Kra, R S, eds, Internatl ${ }^{14} \mathrm{C}$ conf, 12 th, Proc: Radiocarbon, v 28, no. 2A, p 534-538.

Srdoc, D, Horvatincic, N, Obelic, B and Sliepcevic, A, 1982, Rudjer Boskovic Institute radiocarbon measurements VII: Radiocarbon, v 24, no. 3, p 352-371.

1983, Radiocarbon dating of tufa in paleoclimatic studies, in Stuiver, $M$ and Kra, $\mathrm{R} \mathrm{S}$, eds. Internatl ${ }^{14} \mathrm{C}$ conf, $11 \mathrm{th}$, Proc: Radiocarbon, v 25, no. 2, p 421-427.

Srdoc, D, Obelic, B, Horvatincic, N and Sliepcevic, A, 1980, Radiocarbon dating of calcareous tufa: How reliable results can we expect? in Stuiver, $\mathrm{M}$ and $\mathrm{Kra}, \mathrm{R} \mathrm{S}$, eds, Internatl ${ }^{14} \mathrm{C}$ conf, 10th, Proc: Radiocarbon, v 22, no. 3, p 858-862.

Stuiver, $M$ and Polach, H A, 1977, Discussion: Reporting of ${ }^{14} \mathrm{C}$ data: Radiocarbon, v 19 , no. 3, p 355-363.

Szulc, J, 1983, Genesis and classification of travertine deposits: Przeglad Geol, v 31, p 231236 Ph D thesis, Polish Acad Sci, Cracow.

1986, Holocene travertine deposits of the Cracow Upland, in IAS 7th European mtg: Excursion Guidebook, Cracow, p 185-189.

Thorpe, P M, Holydak, D T, Preece, R C and Willing, M J, 1981, Validity of corrected ${ }^{14} \mathrm{C}$ 
dates from calcareous tufa, in Formations carbonatées externes, tufs et travertins: Actes Colloques AGF, Paris, p 151-156.

Thorpe, P M, Otlet, R L and Sweeting, M M, 1980, Hydrological implications from ${ }^{14} \mathrm{C}$ profiling of UK tufa, in Stuiver, $\mathrm{M}$ and $\mathrm{Kra}, \mathrm{R} \mathrm{S}$, eds, Internatl ${ }^{14} \mathrm{C}$ conf, 10th, Proc: Radiocarbon, $v 22$, no. 3 , p $897-908$.

Urbanski, J, 1932, Przyczynek do znajomosci mieczakow miedzylodowcowych trawertynow z Gliczarowa pod Zakopanem: Roczniki PTG, v 8, p 205-209.

Usdowski, E, Hoefs, J and Menschel, G, 1979, Relationship between ${ }^{18} \mathrm{C}$ and ${ }^{18} \mathrm{O}$ fractionation and changes in major element composition in a recent calcite-depositing spring: a model of chemical variations with inorganic $\mathrm{CaCO}_{3}$ precipitation: Earth Planetary Sci Letters, $\mathrm{v}$ 42, p 267-276. 